\title{
THE INFLUENCE OF CHRONIC STRESS ON HEALTH AND COPING MECHANISMS
}

\author{
Cvjetković Bošnjak Mina, ${ }^{1,2}$ Dubovski Poslon Milota, ${ }^{1,2}$ Bibić Željko, ${ }^{3}$ Bošnjak Kristina ${ }^{4}$ \\ ${ }^{1}$ Clinic of psychiatry, Clinical centre of Vojvodina, Novi Sad, Serbia \\ ${ }^{2}$ Faculty of medicine Novi Sad, University of Novi Sad, Serbia \\ ${ }^{3}$ General hospital Vrbas, Psychiatry department, Vrbas, Serbia \\ ${ }^{4}$ Faculty of sciences, Department of biology and ecology, Novi Sad, Serbia
}

Primljen/Received 09. 12. 2018. god.

Abstract: Stress represents a negative life experience, closely followed by physiological, cognitive, emotional, and behavioral changes that focus on changing the event or adapting to its effects. Any situation or occurrence that requires adaptation can be experienced as a stress, even positive situations and circumstances may be stressful, whether they come from the outside world, or the sources of stress is internal. While acute stress does not necessarily have a negative effect, if it lasts for a long time, or is frequently repeated, it becomes chronic, and can cause various serious disorders. During chronic stress, there is an exhaustion of the body's capacity for an adequate reaction, which can lead to long-lasting immunological dysfunction, which significantly impairs health and quality of life. According to the WHO (2017), stress is one of the causes of even $60 \%$ known diseases, and in a number of mental disorders a direct connection with stress has been reported: in acute stress reactions, "posttraumatic stress disorder", adjustment disorders and other reactions to severe stress. In addition, in all categories of mental disorders (ICD-10), the stressful situation or event plays a significant role in occurrence of the symptoms. A particular category of stress-related disorders are psychosomatic disorders. These are functional disorders in which there is no pathoanatomic substrate. In contrast to these, psychosomatic diseases are the type of illness in which there are structural changes of tissues and organs, the etiology of which is based on chronic stress, in addition to a number of other factors (Adamović, 1983) and which occur when there is a biological predisposition. The paper presents the mechanism of development of these diseases and some of the ways of coping with stress. According to the DSM-V, psychosomatic diseases are divided into skin diseases,
Prihvaćen/Accepted 22. 01. 2019. god.

gastrointestinal diseases, respiratory diseases, heart and blood vessel diseases, disorders of endocrine glands, rheumatoid diseases, gynecological diseases and others. In order to overcome stress and preserve health, psychological strategies for coping with stress play an important role. Multiple strategies are used, which include various stress control techniques: relaxation techniques, meditation methods, and assertive training, biofeedback and stress inoculation techniques. Successful mastering of coping stressful situations, constructive problem solving in life crisis, relaxation techniques and contributions to better adaptation to unexpected changes in life are of key importance for both mental and physical health.

Key words: stress, psychosomatic diseases, coping stress strategies.

\section{INTRODUCTION}

Nowadays, the concept of stress has been adopted, both in professional circles and among layman and is used to explain many phenomena in everyday life $(1,2$, $3)$. To what extent does stress represents a medical problem, indicates WHO (World Health Organization) report, which proclaimed 20th century as "the century of collective and individual stresses in epidemic proportions and various forms, unseen so far in the history of the human race." Thus, over the past century, stress became a critical factor in maintaining health and the cause of psychosomatic diseases.

Stress represents a negative life experience, closely followed by physiological, cognitive, emotional, and behavioral changes that focus on changing the event or adapting to its effects. Stress is indeed the result of a subjective assessment of a particular person who lacks ca- 
pacity to adapt to the newly emerging situation. Every situation or event that requires adaptation can be experienced as stress $(3,4,5)$. This implicates that stress can represent not only negative, but also positive situations and circumstances: marriage, relocation, starting school etc. In addition to the "external", there are "internal" stressors, such as illness, perfectionism, unrealistic expectations, and so on. If it lasts for a long time, or is repeated frequently, acute stress becomes chronic, which is the cause of a whole range of disorders $(2,3)$.

There are various definitions of stress, however, one of the most frequently quoted is the one by Lazarus (1950): "A subjective assessment of the events includes the assessment of the degree of demand and the support that is available in the process of coping with problems". Stressors impersonate external or internal events that cause stress, whereby it is crucial to appraise whether an event is stressful for a particular person or not. This subjective assessment of stressful events leads to changes in psychological functioning, in physiology and in the experience of the entire process which is actually a stress reaction.

Epictetus, Greek philosopher (50-138) stated: "People are not upset by the event itself, but by their own perception of a certain event."

Universal stressors are disasters (earthquakes, floods, wars), traumas (exceptional unpleasant individual experiences like rape or torture), and crises-expected unpleasant life events which represent normal experience, and in most people cause similar reactions. In addition to these high-intensity stressors, there are also chronic low-stress intensity stressors such as unsatisfactory marriage, burnout or poor relationships in the working environment. Nevertheless, in addition to the fact that there are universal stresses, we must bear in mind that the experience of stress is purely individual, having said that, some situations will be experienced by one as stressful, while other will have quite different experience. Reactions are depending on the individual assessment, as well as the capacity of a person to coup with it. When stress exceeds the ability to adapt, it distorts the quality of life and leads to physical or mental disorders. Nowadays, in contemporary literature, the prevailing assumption is that the overcoming of stress represents a mediator of stress. This implicates that stress and various disorders are not directly related to stress itself, but that stress is a factor that triggers prevailing behavior which affect the outcome (3).

Short-term or "acute" stress does not necessarily have negative consequences. This kind of stress is also called "eustress" and it can encourage person to progress and to achieve success. In the state of "eustress", one is conscious, with sharpened attention and perception, with shortened reaction time, (e.g. exam, job interview, etc.). Distress, however, means that there is no way to overcome the stressful situation, which makes individuals helpless and significantly jeopardizes our sense of well-being (3).

Acute stress occurs within a few minutes as a response to a strong stressor, causing a defensive reaction which causes the individual to experience the feeling of physical and psychological fatigue. Some individuals during the acute stress may experience muscle paralysis ("paralyzed from fear"), while other experience- "fight-or-flight response". In the first phase, organism prepares for action and the adrenal cortex is activated through the sympathetic nervous system leading to an increase blood levels of adrenaline and noradrenaline. As a result of this, heart rate increases as well as blood pressure, glycaemia rises and the sweat glands are stimulated. Frequent urination, vomiting, or diarrhea may also be associated symptoms $(1,4,5)$.

In the second phase, which occurs several minutes later, hypothalamic-pituitary-adrenal axis is activated which leads to hypercortisolaemia. This axis has the opposite effect on the organism from the sympathetic-adrenal-medullary axis. It ensures preservation of the body and energy and it also engages in passive behavior and avoidance $(1,4,6,7)$.

However, over chronic stress, we notice exhaustion of the body's capacity for adequate fight- or-flight response, and chronic hypersecretion of glucocorticoids leads to volume reduction in the hippocampus and hypothalamus $(6,7,8)$. In the same time, chronic stress, according to modern knowledge, leads to long-lasting immunological dysfunction, which at the end disturbs health and quality of life (8).

During chronic stress, the high level of cortisol is prolonged, which leads to a reduced immune response and functional disorder of normal immune response (there is an increased risk for autoimmune disorders due to the production of pro-inflammatory substances responsible for the emergence of chronic inflammatory diseases) and they also increase the risk of developing some of the autoimmune diseases such as lupus, rheumatoid arthritis, fibromyalgia, etc.).

In 2017 . WHO stated that for $60 \%$ of known diseases one of the causes is stress $(7,8)$. Much less surprising is the fact that many mental disorders are caused by stress, where we can trace direct association such as in the acute stress reaction, posttraumatic stress disorder, adjustment disorders, and other reactions to severe stress. In addition, in all categories of mental disorders (ICD-10), the stressful situation or event plays a significant role in occurrence of the symptoms.

\section{PSYCHOSOMATIC DISORDERS}

It was already known in ancient times that exposure to long-lasting stress, as well as various emotional 
states, could lead to physical illness. Socrates (470-300 BC) stated during the treatment of numerous bodily diseases that the body cannot be cured if "the soul is not healed". He also believed that any problem that patient has and is unsolvable to him can cross into the physical sphere and become bodily disease. The term "psychosomatic" was first used in 18th century by Hainroth, who cited numerous physical disorders that he connected with the influence of strong emotions. G. Groddeck (1866-1934), who advocated for the holistic treatment of every physically ill patient, is regarded as a pioneer of psychosomatic medicine. In the beginning of the 20th century, interest in psychosomatic disorders was growing, and in scientific circles there was an increasing number of publications citing chronic stress as a possible cause of many bodily illnesses. In the basis of psychosomatic diseases, somatization is actually a mechanism by which emotional content is transformed into the body sphere, and the pathological substrate occurs when the flow of anxiety through the body becomes dominant in the "emptying of an excess of anxiety." This leads to the manifestation of psychosomatic disorders or psychosomatic diseases $(8,9,10)$.

Psychosomatic disorders are functional disorders caused by stress, and without a pathoanatomic basis, while in psychosomatic diseases there are structural disorders of organ and organic systems and chronic stress in addition to a number of other etiological factors, plays a crucial role (8).

A link that connects chronic stress with physical illnesses is certainly a neuroendocrine and immune system, but so far pathophysiological mechanisms are not clear enough.

Franz Alexander, (1891-1964) described the "big 7" diseases in whose genesis, stress plays a key role. These are: arterial hypertension, gastroduodenal ulcer, ulcerative colitis, hyperthyroidism, asthma, chronic poli-rheumatism and neuro-dermatitis. His interpretation was that the etiology of these diseases were most commonly unpleasant emotions but when there was a biological predisposition. Emotions responsible for the onset of the psychosomatic disease are most often suppressed aggression and jealousy that are caused by psychological trauma in childhood. In doing so, psychosomatic symptoms are a form of stress release in the absence of a more convenient way.

The latest classification of the American Psychiatric Association (DSM-5, 2013) classifies psychosomatic diseases as follows:

1. Dermatological diseases (acne, urticaria, neurodermitis, angioneurotic edema)

2. Digestive system diseases (ulcer, constipation, irritable bowelsyndrome, Crohn's disease)
3. Respiratory system diseases (asthma, tuberculosis)

4. Heart and blood vessels (hypertension, angina pectoris, arrhythmias)

5. Endocrine disorders (diabetes, hyperinsulinism, and hyperthyroidism)

6. Rheumatic diseases (chronic back pain, lumbar syndrome, polyurheumatism)

7. Gynecological diseases (dysmenorrhea, spontaneous abortion)

8. Other (obesity, overeating, migraines, tumors)

It is evident that the number of psychosomatic diseases is on the rise, and therefore it is necessary for therapeutic purposes to include psychotherapeutic interventions in all the above disorders.

\section{COPING STRESS STRATEGIES}

Coping stress strategies involve the activation of external and internal capacities in the fight against stress which means reduction of the "threat" to the personality, changing of what is possible and acceptance of the occasions that overcome personal or human possibilities $(11,12,13)$.

Successful coping strategies aim to maintain a positive self-image, preserve emotional stability and maintain stable social relationships.

According to Lazarus and Folkman (1950), strategies for overcoming stress involve direct external actions directed towards solving problems or escaping from problems, as well as intrapsychic actions aimed at mitigating emotional consequences (redefining, activating defense mechanisms).

Successful strategies for coping stress include:

1. Confronted overcoming which represents active approach to dealing with the source of stress, an assertive "attack" on the problem with maintenance of the internal locus of control.

2. Mastery planning- orientation toward the problem and solution, but with the preliminary elaboration of tactics and searching for additional information for a better understanding of the situation.

3. Seeking social support from the environment, which means that the aid is actively sought or expected, as well as obtaining emotional support or additional information from other people.

4. Establishing self-control, which implies distancing of problems and being calm or "cool headed." It is advisable that in some situations postponing reactions and problem solving are much better than to succumb to impulsive behavior.

5. Finding positive meanings and suppressing the negative consequences of stressful situations that cannot be avoided. 
In overcoming stress psychologists use multiple strategies, which include various stress control techniques such as: relaxation methods, meditation, assertive training, biofeedback, stress inoculation techniques, and others.

\section{AUTOGENIC TRAINING}

The creator of this relaxation technique is a German neuropsychiatrist and psychotherapist Johannes Hainrich Schulz. Schulz, and later his associate Lute, presented autogenic training to the scientific public as a technique of psychophysical relaxation back in 1932.

The mechanism behind the exercise of autogenic training is activation of the so-called relaxed response, which is opposite to the "fight-or-flight" mechanism. Regular practice of this technique leads to the re-establishment of homeostasis, which is impaired by long-lasting stress. Autogenic training has positive effects both on physiological and psychological functions $(14,15)$.

The technique of autogenic training is structured as a system of six standard exercises during which the patient, with the help of auto suggestive verbal formulas, releases himself in a state of relaxation. Results are normalizing breathing, regulating blood pressure, improving the quality of sleep, mood stabilizing, reducing anxiety and improving concentration and most cognitive functions.

\section{ASSERTIVE TRAINING}

Assertive training is training in communication skills and self-confidence. By mastering this technique, people acquire social and communication skills that enable them to openly communicate their wishes or feelings to others, and thus achieve their goals.

The effects of applied assertive training are manifested in the reduction of anxiety, stress, shyness, ability to manage emotions and develop greater sensitivity for other people, and finally self-esteem strengthening.

\section{BIOFEEDBACK}

This technique implies the strengthening of control over one's own psychophysiological functions, with the help of functions feedback that person receives through modern technology. The client learns to recognize physiological responses and to change them (similar to learning to ride a bicycle or playing a piano).
By adopting biofeedback technique clients learn about their own psychophysiological patterns of stress response and how to control them. Skilled arts become automatic and the person use them independently from the therapist after training.

Biofeedback effects are expressed in improving circulation, rhythm of breathing, normalizing blood pressure, reducing muscle tension, improving concentration and achieving relaxation (16).

\section{STRESS INOCULATION THERAPY}

The creator of this technique is Meinchenbaum (1977), and the name itself could be translated as "stress immunization". During the application of this technique, a therapist teaches the client to recognize his emotions and situations that trigger a certain (irrational) thinking, which is the generator of negative emotions. The next step in this technique is learning new and more effective ways to deal with stressful situations. The client and therapist are exercising together new patterns of thinking and behavior in real life situations that previously represented a trigger for stress responses.

\section{CONCLUSION}

Stress is a disease of the modern way of life. Nowadays, man is facing more and more demands in every walk of life. The alienation, which occurs with technological advances, grows bigger and bigger and it gives rise to loneliness which the plaque of modern man. The sources of stress are numerous, both external and internal. Methods of dealing with stressful situations, constructive resolution of problems in crisis situations, relaxation techniques, as well as better adaptation to unexpected changes in life are of key importance for both mental and physical health. Since stress situations often cannot be completely avoided, it is useful to look at them as a source of new experiences, challenges and possible progress.

\section{DECLARATION OF INTEREST}

The authors declare that there are no conflicts of interest.

\section{Licensing}

This work is licensed under a Creative Commons Attribution 4.0 International (CC BY 4.0) License. 


\title{
Sažetak
}

\section{UTICAJ HRONIČNOG STRESA NA ZDRAVLJE I MEHANIZMI PREVAZILAŽENJA STRESA}

\author{
Cvjetković Bošnjak Mina, ${ }^{1,2}$ Dubovski Poslon Milota, ${ }^{1,2}$ Bibić Željko, ${ }^{3}$ Bošnjak Kristina ${ }^{4}$ \\ ${ }^{1}$ Clinic of psychiatry, Clinical centre of Vojvodina, Novi Sad, Serbia \\ ${ }^{2}$ Faculty of medicine Novi Sad, University of Novi Sad, Serbia \\ ${ }^{3}$ General hospital Vrbas, Psychiatry department, Vrbas, Serbia \\ ${ }^{4}$ Faculty of sciences, Department of biology and ecology, Novi Sad, Serbia
}

Stres predstavlja negativno životno iskustvo, praćeno fiziološkim, kognitivnim, emocionalnim i bihejvioralnim promenama, koje su usmerene na izmenu događaja ili na prilagođavanje njegovim efektima. Svaku situaciju ili događaj, koji zahteva prilagođavanje, možemo doživeti kao stres, tako da stresogeno mogu delovati i pozitivne situacije i okolnosti, bilo da dolaze spolja, ili se radi u unutrašnjim izvorima stresa. Dok akutan stres ne mora imati negativne posledice, ukoliko on traje dugo, ili se učestalo ponavlja, prelazi u hronični, koji može biti uzrok čitavog niza poremećaja. Tokom hroničnog stresa dolazi do iscrpljivanja kapaciteta organizma za adekvatnu reakciju, što može da dovede do dugotrajne imunološke disfunkcije, koja remeti zdravlje i kvalitet života. Prema SZO (2017), čak kod $60 \%$ poznatih obolenja kao jedan od uzročnika navodi se stres, a kod brojnih mentalnih poremećaja je otkrivena direktna povezanost sa stresom: kod akutne reakcije na stres, ,posttraumatskog stresnog poremećaja“, poremećaja prilagođavanja i drugih reakcija na težak stres. Pored toga, kod svih kategorija mentalnih poremećaja

\section{REFERENCES}

1. Selye H. The stress of life. Rev. ed, New York: McGraw -Hill. 1976.

2. Michaud K, Matheson K, Kelly O, Anisman H. Impact of stressors in a natural context on release of cortisol in healthy adult humans: A meta-analysis. Stress. 2008; 11(3): 177-97.

3. Guilliams TG, Edwards L. Chronic stress and the HPA axis. The standard. 2010;9(2): 1-12.

4. Dhabhar FS. Effects of stress on immune function: the good, the bad, and the beautiful. Immunol Res. 2014; 58(2-3): 193-210.

5. Toyofuku A. From psychosomatic dentistry to brain dentistry. Kokubyo Gakkai Zasshi. 2007; 74(3): 161-8.

6. Kato N, Nishimura T, Imai H, Liy Y. Corticosteron and cytokines in the hippocampus. Neurotoxicity vs neuroprotection. Int. J. Neuropsychopharmacol. 2000; 3:S 43.

7. Mather L. Burnout and sick leave due to mental disorders: heritability, comorbidity, risk factors and adverse outcomes. Karolinska Institutet, Division of Insurance Medicine, 2017.

8. Adamovic V. Emocije i telesne bolesti. Beograd: Nolit, 1983.

9. Schneider G, Gieler U. Psychosomatic dermatology-state of the art. Z Psychosom Med Psychother. 2001; 47(4): 307-3.
(MKB-10), stresna situacija ili događaj imaju značajnu ulogu u ispoljavanju simptoma. Posebnu kategoriju poremećaja izazvanih stresom predstavljaju psihosomatski poremećaji. Radi se o funkcionalnim poremećajima kod kojih ne postoji patoanatomski supstrat. Za razliku od njih, psihosomatske bolesti su svrsta obolenja kod kojih postoje strukturni poremećaji organa ili organskih sistema, u čijoj etiologiji, pored niza drugih činilaca, hronični stres ima presudnu ulogu (Adamović, 1983) i koje nastaju kada za to postoji biološka predispozicija. U radu je objašnjen mehanizam nastanka ovih bolesti i načina prevazilaženja stresa koji se smatra njihvim glavnim okidačem. Prema DSM-V psihosomatska obolenja se dele na kožne bolesti, bolesti probavnog sistema, bolesti respiratornih organa, bolesti srca i krvnih sudova, bolesti žlezda sa unutrašnjim lučenjem, reumatske bolesti, ginekološke bolesti i ostalo. U cilju prevazilaženja stresa i očuvanja zdravlja, značajnu ulogu imaju psihološke strategije.

Ključne reči: stres, psihosomatske bolesti, strategija suočavanja sa stresom.

10. Kvillemo P. Coping and stress management training with special focus on women with breast cancer. Karolinska Institutet, Division of Insurance Medicine, 2017.

11. Rahman S. Disability pension due to common mental disorders - subsequent psychiatric morbidity and suicidal behaviour. Karolinska Institutet, Division of Insurance Medicine, 2017.

12. Hafner S, Emeny RT, Lacruz ME, Baumert J, Herder $\mathrm{C}$, Koenig $\mathrm{W}$ et al. Association between social isolation and inflammatory markers in depressed and non-depressed individuals: Results from the MONICA/ KORA study. Brain Behav Immun. 2011; 25(8): 1701-7.

13. Shivpuri S, Gallo LC, Crouse JR, Allison MA. The association between chronic stress type and C-reactive protein in the multi-ethnic study of atherosclerosis: does gender make a difference? J Behav Med. 2012; 35(1): 74-85.

14. Berger D. Zdravstvena psihologija, 1st ed.Beograd: Centar za primenjenu psihologiju, 1997.

15. Vasić G, Mihajlović G. Psihoterapija i psihofarmakoterapija-tiho povezivanje. Engrami. 2008; 30(3-4): 25-34.

16. Tayler SE. Health psychology 3 rd edition New York Mc Graw-Hill, 1995.

\section{Correspondence to/Autor za korespondenciju}

prof. dr Mina Cvjetkovic Bosnjak,

Faculty of medicine Novi Sad, University of Novi Sad e-mail: minacvjet@gmail.com; mina.cvjetkovic@mf.uns.ac.rs tel. 0631523598 